AJHSE Vol: 2 (1): 25-42, 2021

DOI.: 10.52417/ajhse.v2i1.122

Accepted Date: April 19, 2021

(C) 2021. CC License 4.0

www.ajhse.org

\title{
GENETIC DIVERSITY OF Digitaria horizontalis Willd. IN BUILT ENVIRONMENTS IN BENIN CITY, NIGERIA
}

\section{${ }^{* 1,2,5}$ Ikhajiagbe, B., ${ }^{1,3}$ Odenore, V. D., ${ }^{1,4}$ Omoregie, G. O., ${ }^{1}$ Umeokeke E. O., ${ }^{1}$ Ahanor, E. S., ${ }^{1}$ Amadin, O., ${ }^{5}$ Omoigui, I.D., ${ }^{6}$ Loveniers, P. J., \& ${ }^{1,5}$ Anoliefo G.O.}

\begin{abstract}
${ }^{5}$ Department of Plant Biology and Biotechnology, University of Benin, Benin City
${ }^{6}$ Faculty of Bioscience Engineering, University of Ghent, Belgium

*Correspondence Author Email: beckley.ikhajiagbe@uniben.edu

*ORCID: https://orcid.org/0000-0003-2834-7447
\end{abstract}

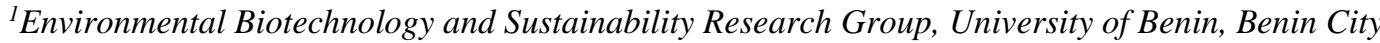

${ }^{2}$ Applied Environmental Bioscience and Public Health Research Group, University of Benin, Benin City

${ }^{3}$ Physiology Division Nigerian Institute for Oil Palm Research, Benin City, Edo State

${ }^{4}$ Department of Environmental Management and Toxicology, Federal Univeristy of Petroleum Resources, Effunrun, Nigeria

\begin{abstract}
7 he influence of humans on biodiversity at the genetic, species, community, and ecosystem levels is enormous. This is even more impactful on plant populations, which, being immobile, are at the mercy of 1 their immediate environment. Digitaria horizontalis is a very common grass species in Benin City. Its
\end{abstract} ruderal nature accounts mostly for its widespread. The current study investigated the existence of possible genetic diversity of the grass in built environment in Benin City. Plant samples were randomly collected from 21 built environment locations within 6 Local Government Council Areas that make up Benin City. Test plants were allowed to acclimatize in experimental bowls and then allowed to grow for 4 weeks after which morphological characteristics were determined. Genetic diversity was determined by Random Amplification of Polymorphic DNA. Significant differences in plant height $(33.0-59.0 \mathrm{~cm})$ occurred when plants were compared based on location of collection. Changes in patterns of the association with weeds within the vicinity of the test plant was observed. The most prevalent plant species associated with the test plant was Pennisetum purpureum with a $12.18 \%$ prevalence. RAPD analysis using primer OPA 04 revealed a locus (about 600bp) that was absent in one or more of the locations with minimum disturbance. This 600pb fragment was however observed in most samples from highly built up and trampled environments. Primer OPA 03 showed monomorphic bands in 2 test samples with a band size of 400bp. It is therefore reported that there is an existence of the genetic diversity in a landscape of grass species (Digitaria horizontalis) found in different built environment in Benin City, Edo State, Nigeria.

Keywords: Digitaria horizontalis, built environment, RAPD, genetic diversity, polymorphism

LICENSE: This article by African Journal of Health, Safety and Environment (AJHSE) is licensed and published under the Creative Commons Attribution License 4.0 International License, which permits unrestricted use, distribution, and reproduction in any medium, provided this article is duly cited.

COPYRIGHT: The Author(s) completely retain the copyright of this published article.

OPEN ACCESS: The Author(s) approves that this article remains permanently online in the open access (OA) mode. 


\section{INTRODUCTION}

Industrialization has always seemed to be the key to prosperity and a better life, but studies have shown that, while it enhances living conditions in certain respects, it has a detrimental effect on the ecosystem and, as a result, threatens plant biodiversity (Pariente, 2002). Not only does it involve technological innovations, it also involves economic and social transformation of the human society (Borrelli, 2017). With industrialization come prospects as well as challenges. The challenges include managing changes in the environment (Linares et al., 2011). Due to these challenges, industrialization must take into account plant biodiversity disturbances and its consequences (Mligo, 2011). Plants play a key role in conserving ecosystems. They are a source of food and medicinal compounds while also providing raw materials for many industries. Rapid deforestation and industrialization, however, threaten plant biodiversity. In turn, this threatens the ecosystem (Maynard et al., 2013). Biodiversity of plants ensures a resource for new food crops and medicines. Plant life balances ecosystems, protects watersheds, mitigates erosion, moderates climate, and provides shelter for many animal species (Shrestha et al., 2012). One of such plants with these characteristics is Digitaria horizontalis.

Digitaria horizontalis is a tropical plant that can be found in tropical America as well as West and Central Africa. It can grow rapidly and has developed itself as a dominant species in intensively cultivated fields (Johnson, 1997). In terms of socioeconomic importance, the plant species belongs to one of the most important classes of Poaceae. The use of $D$. horizontalis as a source of fodder (Harun et al., 2017) and in pharmacopoeia are also important socio-economic factors (Pare et al., 2016). It can be found in a variety of environments, but open areas or grasslands tend to have the most diversity. Disturbed areas, such as gardens and cultivated fields, are suitable habitats for these grasses. Digitaria horizontalis is widely used as a lawn plant in horticulture, where it provides aesthetic value while also aiding in the improvement of soil nutrient capability (Ruprecht et al., 2009). Decoction of the plant is used in the treatment of gonorrhea. It is used as folk remedy for cataracts and debility. It is also said to be emetic. Fiber from the plant can be used for making paper. Its forage has an excellent quality and palatability (Latty et al., 2004). The plant's ability to grow and root makes it an ideal choice for soil erosion prevention strategies. The warm-season annual Digitaria horizontalis germinates, grows, and dies all in the same year. Each Digitaria horizontalis plant can produce up to 150,000 seeds during its growth. Those seeds remain in the field, ready to germinate the following season and repeat the cycle. Seeds that do not germinate right away can still be viable and germinate in subsequent years. These characteristics ensure its availability throughout the year.

Genetic diversity is of fundamental importance in the continuity of a species as it provides the necessary adaptation to the prevailing biotic and abiotic environmental conditions, and enables change in the genetic composition to cope with changes in the environment. Grasses are able to survive regular cutting or grazing as their growing points are situated at the base of the plant (Mishra et al., 2004). Lateral shoots (known as tillers) grow from the base of the main shoot, and when the upward growth of these is prevented by grazing; new buds are formed at their base and grow out laterally into new vegetative branches. In this way, grasses are adapted to tolerate grazing, cutting and trampling (Bell et al., 2016).

Many grassy areas are mown, especially in towns and cities. Mowing cuts the plants, and the cut material is often removed. Mowing may also have a crushing effect if heavy machinery and rollers are used. As a result of 
trampling and mowing it is often easy to see a change in the height of the vegetation and both can result in changes to soil conditions as a result of compaction (Blanco et al., 2015). Plants growing on trampled areas have to be tolerant to soil compaction and its effects on soil conditions (Anonymous, n.d.). However, the species composition of the plant community will also be influenced by a number of other interacting factors (Bhuyan et al., 2003). Physical damage to plants by removal of growing tips and crushing occurs, so having the right growth form is important. Deposition of litter and dog fouling may cause changes in the soil mineral content though any change is difficult to measure without sophisticated equipment (Augusto et al., 2002). Relatively few species are likely to be able to survive when environmental conditions are extreme for example in most trampled areas where the chance of physical damage is high and the soil is very compacted. Also, in non-trampled areas where the vegetation is tall and there is strong competition for light. It is at the boundary between the two extremes that the greatest number of species is usually found (Bickham, 2013). At the edge of a trampled areas species are least affected by trampling but avoid too much competition with the more vigorously growing species. The aim of the study was to investigate possible existence of genetic diversity in a landscape grass species (Digitaria horizontalis) found in different built environment in Benin City, Edo State, Nigeria.

\section{MATERIALS AND METHODS}

\section{STUDY AREA}

Six Local Government Areas (LGAs) were visited with 20 built areas with the least altered environment. The LGAs included Ikpoba Okha, Ovia North East, Egor, Orhionmwon, Uhumnwonde, and Oredo LGAs respectively. The control site was the Botanic Garden located at Site B (or otherwise called Capitol) of the Ugbowo campus of the University of Benin, Benin City.

\section{CAPITOL (A)}

Botanic Garden located at Site B of the Ugbowo campus of the university, or otherwise referred to in the study as the Capitol is an area around the University of Benin that is minimally developed. It served as control because in comparison to other locations it did not contain buildings. Its bearing is $270^{\circ} \mathrm{NW}$. It lies on latitude $6^{0} 20^{\prime} 1.32^{\prime \prime} \mathrm{N}$ and longitude $5^{0} 36^{\prime} 0.53^{\prime}$ 'E. This area is very rich in biodiversity.

\section{UNIVERSITY OF BENIN HALL 1 HOSTEL (B)}

This is a built area, a hostel in the University of Benin for females. It is a highly disturbed area because the grasses are always mowed, trampled and all other soil factors. It is $119^{\circ}$ SE. Its latitude is $6.3965 .8^{\prime} 23^{\prime \prime}$ and longitude 5.6 $18^{\prime} 69^{\prime \prime}$

\section{INE FILLING STATION (C)}

Also located in Ovia North East L.G.A. It is a built area; a filling station. The area is highly disturbed. It serves the municipal town of Ovia North East. Its bearing is $83^{\circ} \mathrm{E}$. It lies on latitude $6^{0} 20^{\prime} 4.35$ and longitude $5^{0} 37^{\prime} 19.3^{\prime \prime}$. 


\section{EVIDENCE CHURCH (D)}

The area was water-disturbed at the time. It is a highly disturbed location. Its bearing is $83^{\circ} \mathrm{E}$. It lies on latitude $\mathrm{N}$ $6^{0} 25^{\prime} 24$ and longitude E 5 $36^{\prime} 6$.

\section{EGOR SECRETARIAT (E)}

It is located at Uselu Market. along Mela Road. It is one of the serving eighteen L.G.A. Councils of the State. Court weddings are carried out here and other activities. This area is highly disturbed. It is constantly mowed and trampled. Its bearing is $336^{\circ} \mathrm{NW}$. It lies on latitude $\mathrm{N}^{0} 22^{\prime} 25$ and longitude $\mathrm{E} 5^{0} 36^{\prime} 53$.

\section{MELA MOTEL (F)}

This area is constantly trampled (especially by cars) and a very busy environment. Its bearing is $268^{\circ} \mathrm{W}$.It lies on latitude $6^{0} 22^{\prime} 20^{\prime}$ 'N and longitude 5036'34'’E.

\section{EDAIKEN (G)}

Although this area is built, it is not very disturbed. In fact, it is very rich in weed biodiversity. Its bearing is $251^{\circ} \mathrm{SW}$. It is also located in Egor local government area. It lies on latitude $6^{0} 22^{\prime} 08^{\prime}{ }^{\prime} \mathrm{N}$ and longitude $5^{0} 36^{\prime} 59^{\prime}$ 'E.

\section{EDOKPOLOR GRAMMAR SCHOOL (H)}

This a secondary school in Oredo L.G.A, around the New Benin axis of the State Capital. It is a highly disturbed area. This area is always trampled by vehicles and humans. Mowing is always done on this location. Its bearing is $305^{0}$ NW'. It lies on latitude $6^{0} 21^{\prime} 18^{\prime \prime} \mathrm{N}$ and longitude $5^{0} 37^{\prime} 46^{\prime \prime} \mathrm{E}$.

\section{NEW CONVENANT GOSPEL CHURCH, NEW BENIN (I)}

This place is highly developed and highly disturbed. Most part of the land has been graded and completely devoid of plant life. It is on a bearing of $40^{\circ} \mathrm{NE}$. It lies on a latitude $6^{0} 21^{\prime} 20^{\prime}{ }^{\prime} \mathrm{N}$ and longitude $5^{0} 37^{\prime} 44^{\prime \prime} \mathrm{E}$.

\section{NEW BENIN CEMETERY (J)}

Located around the New Benin axis, it is a built area with very rich biodiversity. It is $81^{0} \mathrm{E}$. It lies on a latitude 6021'19''N and longitude 5037'34''E.

\section{OANDO FILLING STATION (K)}

This petrol filling station is located outside New Benin, just on the axis of Ikpoba Slope. It is highly disturbed with cars driving through and it is always trampled. Its bearing is $81^{\circ} \mathrm{E}$. It lies on latitude $6^{0} 21^{\prime} 19^{\prime \prime} \mathrm{N}$ and longitude $5^{0} 37^{\prime}$ 'E. 


\section{IKPOBA BRIDGE, AKPAKPAVA (L)}

This is the bridge that crosses the Ikpoba River along the Akpakpava/Ikpoba Slope axis. This area is very rich in biodiversity although quite disturbed. Its bearing is $230^{\circ} \mathrm{SW}$. It lies on latitude $6.35116^{\circ} \mathrm{N}$ and longitude $5.6470^{\circ} \mathrm{E}$. AVBIAMA ROAD (M)

Avbiama is a disturbed area that is extremely trampled. There are a lot of shops in this area. Its bearing is $94^{0} \mathrm{E}$. It lies on latitude N6 ${ }^{0} 20^{\prime} 51$ and longitude E $5^{0} 38^{\prime} 52$.

\section{OREGBENI (N)}

Oregbeni samples were collected around the popular Oregbeni Market axis around Ramat Park, Ikpoba Hill. Its bearing is on $131^{\circ} \mathrm{SE}$. This is an urbanized area that has lots of shops around it. It lies on latitude and longitude.

\section{RAMAT PARK (O)}

This is a highly urbanized area on the Ikpoba Hill, with a lot of activities. Trampling is extreme in this location by local township vehicles and also humans. It lies on latitude $6.35006^{\circ} \mathrm{N}$ and longitude5.6 $612^{\circ} \mathrm{E}$.

\section{BYPASS ROAD (P)}

The bypass is off Eyean on the Benin-Auchi axis. There was no land mark around this area. Although the area is highly disturbed, there were a diverse species of grass in this area. Its bearing is $164^{\circ} \mathrm{SE}$. It lies on latitude $\mathrm{N} 6^{0} 22^{\prime}$ 48 and longitude $\mathrm{E} 5^{0} 42^{\prime} 22^{\prime}$.

\section{PIPELINE ROAD (Q)}

A lot of human activities take place here. It has a lot of built areas ranging from shops to family homes. It is very rich in biodiversity regardless. Its bearing is $121^{\circ} \mathrm{NW}$. It lies on latitude $\mathrm{N} 6^{0} 23^{\prime} 18^{\prime}$ and longitude E $5^{0} 38^{\prime} 19^{\prime}$.

\section{IGUOMO ROAD (R)}

This is an area that has experienced trampling and other human activities. It is $268^{\circ} \mathrm{W}$ and it is located at Orhionmwon L.G.A. It lies on latitude N 60 20' 17 and longitude E 5044'14.

\section{REHEEBOOTHS FOOD AFFAIR (S)}

This is a popular restaurant located off Iguomo area in Orhionmwon local government area. Trampling activities is prevalent in this area, especially with parked cars. Its bearing is $121^{\circ} \mathrm{N}$. It lies on latitude $\mathrm{N} 6^{0} 29^{\prime} 11^{\prime}$ and longitude E $5033 " 15$,

\section{MAY-EWERE AND CO. GAS STATIONS (T)}

This area is a gas station which means that it has lot of cars visiting the area. Trampling is also prevalent in this area. It is located at Orhionmwon L.G.A. Its bearing is $124^{\circ} \mathrm{NW}$. It lies on latitude N $6^{0} 25^{\prime} 12$ and longitude E $5^{0} 27^{\prime} 18^{\prime}$ 


\section{BONEDO PETROLEUM NIGERIA LIMITED (U)}

This is an area in Orhionmwon LGA. Trampling is prevalent in this area. $227^{\circ} \mathrm{S}$. It lies on latitude $\mathrm{N} 6^{0} 13^{\prime} 11$ and longitude E $5^{0} 25$ ' 14 '.

\section{COLLECTION OF PLANTS}

Plants were collected from the various areas from A to $\mathrm{U}$ above. Three plants were uprooted each from these areas with a ball of earth. Care was taken to ensure that the plants collected did not show signs of chlorosis and necrosis. Also, the plant had not started flowering when they were uprooted and taken immediately to the Screen House.

\section{TRANSPLANTING AND STABILIZATION}

The plants were brought into already prepared experimental bowls measuring $68 \mathrm{~m}$ in diameter and $43 \mathrm{~m}$ in depth. Soils were collected from the botanical garden and were filled into nursery bags. The plants were transplanted into nursery bags to stabilize. Plants characteristics were eventually measured.

\section{PLANT PARAMETERS ASSESSED}

The cell elongation rate clearly influences overall plant height since cell division is restricted to a small portion of the shoots and roots. The prominent height was determined and was measured with a metre rule. The internode was determined as the portion of plant stem between nodes and was measured with a metre rule. Chlorophyll Content Index was determined by the aid of a chlorophyll content meter; CCM-200 plus, which is a non-destructive chlorophyll content measuring meter, which exploits the distinct optical absorbance characteristics of the chlorophyll in other to determine its relative concentration. The average meter reading of 3 leaves per plant was taken as the CCI. The leaves were counted and the total number recorded. The maximum length of inflorescence was measure from the point where the peduncle attached to the stem to the tip of the inflorescence. In order to determine the leaf area, the leaves were placed on a graph note book and traced. The area covered by the leaf on the graph trace were computed for leaf area.

\section{RANDOM AMPLIFIED POLYMORPHIC DNA (RAPD)}

DNA extraction from the leaf of test plants A - U was carried out using a ZR plant/seed DNA extraction kit according to manufacturer's instruction. Briefly, $150 \mathrm{mg}$ of the test plant leaf was added to a ZR BashingBead ${ }^{\mathrm{TM}}$ containing 750 $\mu \mathrm{l}$ of the lysis solution. The leaf was then homogenized using a mini bead-beater for 10 minutes. After homogenization, the tubes were centrifuged at $10,000 \mathrm{xg}$ for 1 minute. $400 \mu \mathrm{l}$ of the supernatant was transferred into a Zymo-Spin ${ }^{\mathrm{TM}}$ IV Spin Filter in a Collection Tube and centrifuged at 7,000 rpm for 1 minute. 1,200 $\mu 1$ of Plant/Seed DNA Binding Buffer was then be added to the filtrate in the Collection Tube. This mixture was transferred to a Zymo-Spin ${ }^{\mathrm{TM}}$ II Column in a Collection Tube, and centrifuged at $10,000 \mathrm{x}$ g for 1 minute. The flow through from the Collection Tube was discarded and $500 \mu \mathrm{l}$ of Plant/Seed DNA Wash Buffer added to the Zymo-Spin ${ }^{\mathrm{TM}}$ II Column in a new Collection Tube and centrifuged at 10,000 $\mathrm{x}$ g for 1 minute. After repeating the wash step, the column was transferred to a clean $1.5 \mathrm{ml}$ microcentrifuge tube and $100 \mu \mathrm{l}$ of sterile water was added directly to the column matrix after which the tubes was centrifuged at $10,000 \mathrm{x} g$ for 30 seconds to elute the DNA. Finally, the eluted DNA was filtered using a Zymo- 
Spin $^{\mathrm{TM}}$ IV-HRC Spin Filter into a $1.5 \mathrm{ml}$ microcentrifuge tube and centrifuged at 10,000 x g for 30 seconds. Spectrophotometric purity and quantification were carried out on the extracted DNA (Williams et al., 1990; Wilde et al., 1992; Barakat et al., 2010; Atak et al., 2011).

\section{POLYMERASE CHAIN REACTION}

RAPD-PCR was carried out on the extracted DNA sample using the RAPD primer OPA 04 (5' - AAT CGG GCT G 3') and OPA 03 (5'-AGTCAGCCAC-3') The PCR reaction was carried out in a $20 \mu$ reaction mixture containing $1 \mathrm{X}$ PCR buffer (Solis Biodyne), 2.5mM Magnesium Chloride, $0.2 \mathrm{mM}$ of each dNTP, $40 \mathrm{pMol}$ of primer, 1U Taq DNA polymerase, 10-200 ng of DNA, and sterile deionized water was used to make up the reaction mixture (Williams $e t$ al., 1990; Barakat et al., 2010; Yaycili and Alikamanoğlu, 2012). Amplification was carried out in an Eppendorf Nexus thermalcycler using the following cycling parameters; an initial denaturation at $95^{\circ} \mathrm{C}$ for 5 minutes which was followed by 40 consecutive cycles of $95^{\circ} \mathrm{C}$ for 1 minute, $30^{\circ} \mathrm{C}$ for 1 minute and $72^{\circ} \mathrm{C}$ for 2 minutes. This was followed by a final extension of $72{ }^{\circ} \mathrm{C}$ for 10 minutes. The PCR products were separated on a $1 \%$ Agarose gel and $1 \mathrm{~Kb}$ DNA ladder (Fermentas) was used as DNA molecular weight standard.

\section{STATISTICAL ANALYSIS}

Results were presented in Mean of 5 replicates. Analysis of variance in complete by randomized design was done using the SPSS ${ }^{\circledR}$ version 20 statistical software, and means were separated by using the Least Significant Difference. Plant diversity indices were determined using PAST version 2.17c (Hammer et al., 2001).

\section{RESULTS}

Morphological characteristics of test plant collected from the various sampling locations have been presented (Table 1). Prominent plant height ranged from $33.0-59.0 \mathrm{~cm}$ with significant differences occurring when plants were compared based on location of collection. There were no significant differences in internode of plant collected and stabilized (7.5 - $10.1 \mathrm{~cm}, \mathrm{p}>0.05)$. Similarly, no significant differences in maximum length of inflorescence $(\mathrm{cm})$ were observed in the study. An attempt was made to discover which of the measured plant parameters showed more variability when compared with the others (Fig. 1). Results showed that plant leaf area showed more variability.

The abundance of weeds associated with the test plant in the experimental bowls was reported (Table 2). Atotal of 13 plant taxa were identified to be associated with the test plant. The weeds included Asystasia gangetica, Commelina erecta, Lindernia crustacea, Kyllinga nemoralis, Mariscus longibracteatus, Spigelia anthelmia, Phyllanthus amarus, Solenostemon monostachyus, Pennisetum purpureum, Cyperus esculentus, Axonopus fissifolius, Eleusine indica and Eragrostis amabilis. Of the 21 locations, a total of 48 individual Asystasia gangetica species were identified, implying an average of 2 species per unit area (surface area is $79.14 \mathrm{~cm}^{2}$ ). Average plant per unit area was 1 in Spigelia anthelmia, Phyllanthus amarus, Cyperus esculentus, Axonopus fissifolius, Eleusine indica, and 
Eragrostis amabilis respectively. Young Pennisetum purpureum plants were the most abundant per unit area (3 plants) in association with the test plant.

Prevalence of the weeds as well as index of citation was presented in Table 3. The most prevalent plant species associated with the test plant was Pennisetum purpureum (12.18\%). This weed species however had a lower citation index (0.476) than Eleusine indica (0.762). The least prevalence was obtained in Cyperus esculentus (5.34\%). Correspondence biplot and principal coordinates establishing relationship among sampling locations and associated weed species have been presented in Fig. 2(a) and 2(b) respectively. Results showed associateion of Lindernia crustacea with location K. Eleusine indica was mostly associated with $\mathrm{O}, \mathrm{M}$, and G locations. The association of the locations has been presented in Fig. 2(b).

Table 1: Plant morphological parameters at 1 month after transplanting from the various collection locations

\begin{tabular}{|c|c|c|c|c|c|c|}
\hline $\begin{array}{l}\text { Sample } \\
\text { codes }\end{array}$ & $\begin{array}{l}\text { Prominent } \\
\text { plant height } \\
(\mathrm{cm})\end{array}$ & $\begin{array}{l}\text { Internode } \\
(\mathrm{cm})\end{array}$ & $\begin{array}{l}\text { Chlorophyll } \\
\text { content } \\
\text { index (cci) }\end{array}$ & $\begin{array}{l}\text { Number } \\
\text { of leaves }\end{array}$ & $\begin{array}{l}\text { Maximum } \\
\text { length of } \\
\text { inflorescence } \\
(\mathrm{cm})\end{array}$ & $\begin{array}{l}\text { Leaf area } \\
\left(\mathrm{cm}^{2}\right)\end{array}$ \\
\hline A & $35.0^{\mathrm{b}}$ & $8.0^{\mathrm{a}}$ & $1.8^{\mathrm{b}}$ & $25.0^{\mathrm{ab}}$ & $7.5^{\mathrm{a}}$ & $6.4^{\mathrm{a}}$ \\
\hline B & $45.0^{\mathrm{ab}}$ & $7.5^{\mathrm{a}}$ & $5.2^{\mathrm{ab}}$ & $20.0^{\mathrm{abc}}$ & $8.0^{\mathrm{a}}$ & $9.8^{\mathrm{a}}$ \\
\hline $\mathrm{C}$ & $55.0^{\mathrm{a}}$ & $8.3^{\mathrm{a}}$ & $6.4^{\mathrm{a}}$ & $13.0^{\mathrm{d}}$ & $8.4^{\mathrm{a}}$ & $7.2^{\mathrm{a}}$ \\
\hline D & $40.0^{\mathrm{b}}$ & $9.2^{\mathrm{a}}$ & $5.2^{\mathrm{ab}}$ & $15.0^{\mathrm{d}}$ & $7.2^{\mathrm{a}}$ & $4.6^{\mathrm{a}}$ \\
\hline $\mathrm{E}$ & $30.0^{\mathrm{b}}$ & $8.4^{\mathrm{a}}$ & $4.5^{\mathrm{ab}}$ & $10.0^{\mathrm{d}}$ & $4.5^{\mathrm{a}}$ & $7.6^{\mathrm{a}}$ \\
\hline $\mathrm{F}$ & $48.0^{\mathrm{a}}$ & $9.7^{\mathrm{a}}$ & $5.1^{\mathrm{ab}}$ & 13.0 & $7.6^{\mathrm{a}}$ & $5.6^{\mathrm{a}}$ \\
\hline G & $42.0^{\mathrm{b}}$ & $8.4^{\mathrm{a}}$ & $4.2^{\mathrm{ab}}$ & $18.0^{\mathrm{bc}}$ & $7.1^{\mathrm{a}}$ & $5.0^{\mathrm{a}}$ \\
\hline $\mathrm{H}$ & $44.0^{\mathrm{ab}}$ & $10.0^{\mathrm{a}}$ & $6.3^{\mathrm{a}}$ & $17.0^{\mathrm{cd}}$ & $8.5^{\mathrm{a}}$ & $7.4^{\mathrm{a}}$ \\
\hline I & $49.0^{\mathrm{a}}$ & $8.5^{\mathrm{a}}$ & $6.6^{\mathrm{a}}$ & $19.0^{\mathrm{abc}}$ & $8.9^{\mathrm{a}}$ & $4.4^{\mathrm{a}}$ \\
\hline $\mathbf{J}$ & $32.0^{\mathrm{b}}$ & $9.4^{\mathrm{a}}$ & $4.7^{\mathrm{ab}}$ & $16.0^{\mathrm{cd}}$ & $7.9^{\mathrm{a}}$ & $9.3^{\mathrm{a}}$ \\
\hline K & $39.0^{\mathrm{b}}$ & $8.5^{\mathrm{a}}$ & $4.9^{\mathrm{ab}}$ & $23.0^{\mathrm{abc}}$ & $6.2^{\mathrm{a}}$ & $4.9^{\mathrm{a}}$ \\
\hline $\mathrm{L}$ & $45.0^{\mathrm{ab}}$ & $7.9^{\mathrm{a}}$ & $6.8^{\mathrm{a}}$ & $18.0^{\mathrm{bc}}$ & $7.7^{\mathrm{a}}$ & $5.8^{\mathrm{a}}$ \\
\hline M & $44.0^{\mathrm{ab}}$ & $8.1^{\mathrm{a}}$ & $1.8^{\mathrm{b}}$ & $16.0^{\mathrm{cd}}$ & $8.2^{\mathrm{a}}$ & $5.7^{\mathrm{a}}$ \\
\hline $\mathrm{N}$ & $37.0^{\mathrm{b}}$ & $10.1^{\mathrm{a}}$ & $6.1^{\mathrm{a}}$ & $26.0^{\mathrm{a}}$ & $8.4^{\mathrm{a}}$ & $6.2^{\mathrm{a}}$ \\
\hline $\mathrm{O}$ & $32.0^{\mathrm{b}}$ & $9.3^{\mathrm{a}}$ & $4.5^{\mathrm{ab}}$ & $22.0^{\mathrm{bc}}$ & $8.1^{\mathrm{a}}$ & $5.4^{\mathrm{a}}$ \\
\hline $\mathrm{P}$ & $36.0^{\mathrm{b}}$ & $8.2^{\mathrm{a}}$ & $5.7^{\mathrm{ab}}$ & $13.0^{\mathrm{d}}$ & $7.9^{\mathrm{a}}$ & $5.0^{\mathrm{a}}$ \\
\hline Q & $41.0^{\mathrm{b}}$ & $8.4^{\mathrm{a}}$ & $4.5^{\mathrm{ab}}$ & $18.0^{\mathrm{bc}}$ & $8.3^{\mathrm{a}}$ & $6.0^{\mathrm{a}}$ \\
\hline $\mathrm{R}$ & $33.0^{\mathrm{b}}$ & $7.8^{\mathrm{a}}$ & $6.3^{\mathrm{a}}$ & $21.0^{\mathrm{abc}}$ & $8.1^{\mathrm{a}}$ & $4.9^{\mathrm{a}}$ \\
\hline S & $35.0^{\mathrm{b}}$ & $8.0^{\mathrm{a}}$ & $5.2^{\mathrm{ab}}$ & $19.0^{\mathrm{ac}}$ & $8.8^{\mathrm{a}}$ & $5.7^{\mathrm{a}}$ \\
\hline $\mathrm{T}$ & $59.0^{\mathrm{a}}$ & $8.7^{\mathrm{a}}$ & $5.6^{\mathrm{ab}}$ & $16.0^{\mathrm{cd}}$ & $7.2^{\mathrm{a}}$ & $5.4^{\mathrm{a}}$ \\
\hline $\mathrm{U}$ & $52.0^{\mathrm{a}}$ & $8.3^{\mathrm{a}}$ & $6.7^{\mathrm{a}}$ & $17.0^{\mathrm{cd}}$ & $8.3^{\mathrm{a}}$ & $7.8^{\mathrm{a}}$ \\
\hline p-value & 0.281 & 0.437 & 0.368 & 0.002 & 0.179 & 0.224 \\
\hline
\end{tabular}

Means on the same column with similar alphabetic superscripts do not differ from each $(p>0.05)$ 


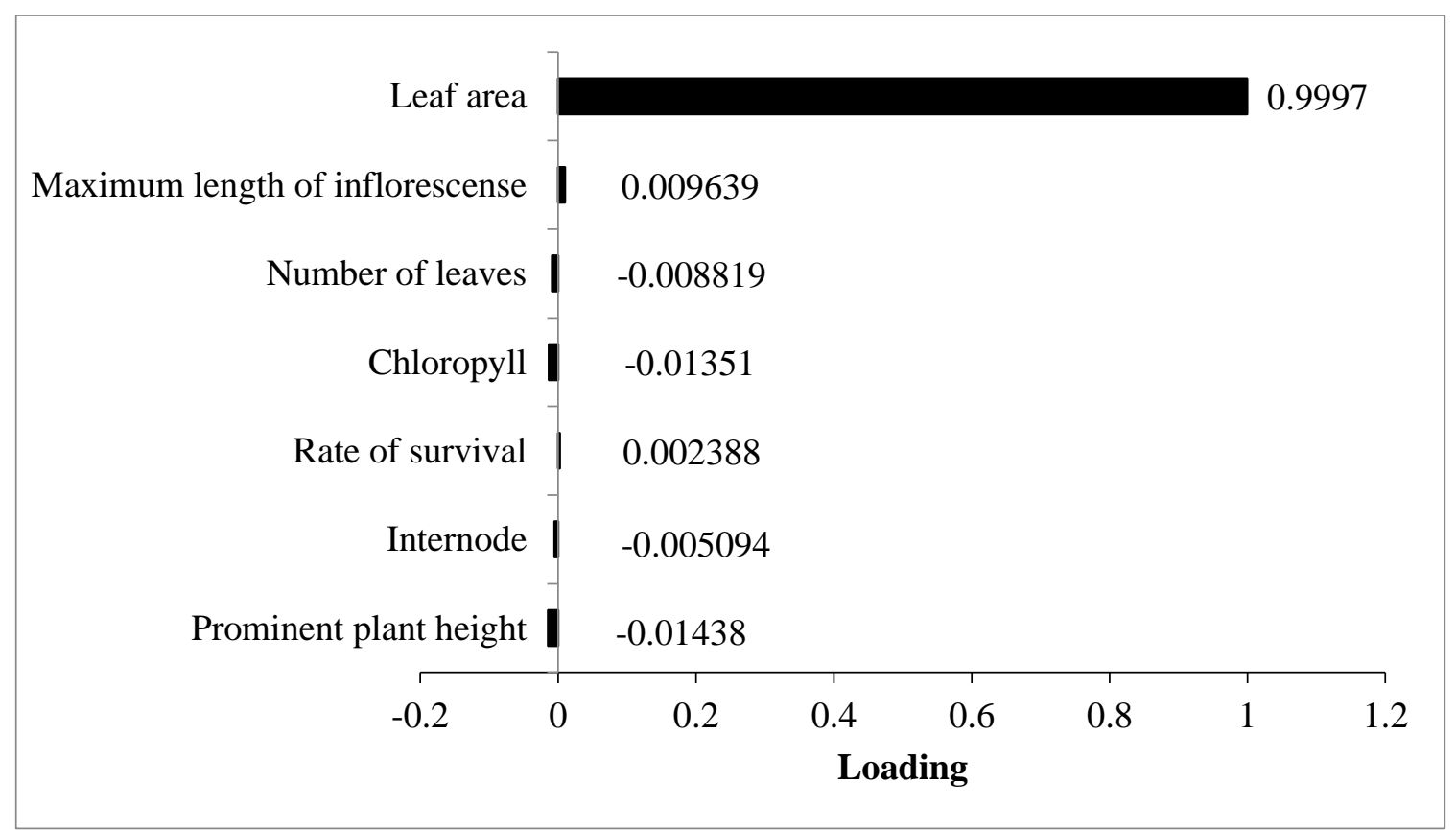

Figure 1: Loading on principal component analysis establishing level of variability in the morphological parameters measured

Table 2: Prevalence and citation index of weed species associated with test plant

\begin{tabular}{llll}
\hline Weed name & Family & $\begin{array}{l}\text { Prevalence } \\
(\%)\end{array}$ & $\begin{array}{l}\text { Citation } \\
\text { index }\end{array}$ \\
\hline Asystasia gangetica & Acanthaceae & 10.26 & 0.476 \\
Commelina erecta & Commelinaceae & 7.05 & 0.571 \\
Lindernia crustacea & Linderniaceae & 9.4 & 0.571 \\
Kyllinga nemoralis & Cyperaceae & 8.12 & 0.667 \\
Mariscus longibracteatus & Cyperaceae & 8.12 & 0.571 \\
Spigelia anthelmia & Longianaceae & 6.62 & 0.571 \\
Phyllanthus amarus & Phyllanthaceae & 6.2 & 0.619 \\
Solenostemon monostachyus & Lamiaceae & 8.55 & 0.571 \\
Pennisetum purpureum & Poaceae & 12.18 & 0.476 \\
Cyperus esculentus & Cyperaceae & 5.34 & 0.667 \\
Axonopus fissifolius & Poaceae & 5.98 & 0.667 \\
Eleusine indica & Poaceae & 5.98 & 0.762 \\
Eragrostis amabilis & Poaceae & 6.2 & 0.571 \\
\hline
\end{tabular}


Table 3: Weed abundance around the test plant per unit area (surface area of experimental bags $=79.14 \mathrm{~cm}^{2}$ )

\begin{tabular}{|c|c|c|c|c|c|c|c|c|c|c|c|c|c|c|}
\hline $\begin{array}{l}\text { Sample code/Weed } \\
\text { name }\end{array}$ & 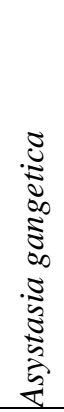 & 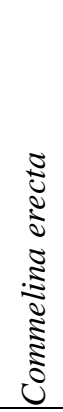 & 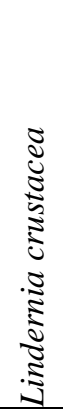 & 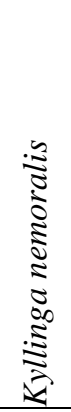 & 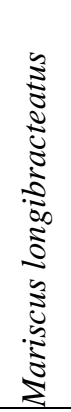 & 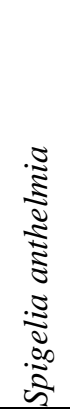 & 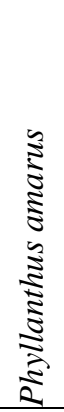 & 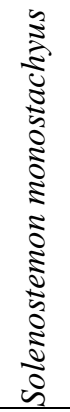 & 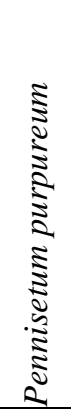 & 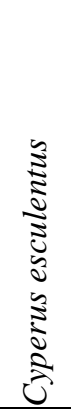 & 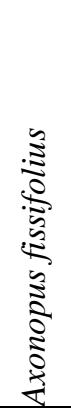 & 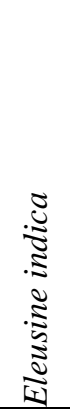 & 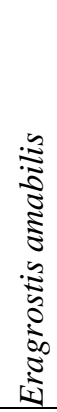 & Total \\
\hline $\mathrm{A}$ & 7 & 0 & 12 & 0 & 0 & 0 & 6 & 4 & 1 & 0 & 0 & 0 & 1 & 31 \\
\hline B & 4 & 3 & 0 & 0 & 3 & 0 & 0 & 7 & 0 & 4 & 1 & 0 & 0 & 22 \\
\hline $\mathrm{C}$ & 0 & 3 & 0 & 0 & 4 & 0 & 0 & 2 & 0 & 0 & 5 & 0 & 3 & 17 \\
\hline D & 1 & 2 & 0 & 5 & 0 & 6 & 4 & 0 & 0 & 0 & 0 & 7 & 0 & 25 \\
\hline $\mathrm{E}$ & 2 & 0 & 0 & 0 & 4 & 0 & 1 & 1 & 11 & 0 & 2 & 0 & 0 & 21 \\
\hline $\mathrm{F}$ & 0 & 0 & 6 & 0 & 0 & 3 & 2 & 0 & 0 & 5 & 0 & 0 & 4 & 20 \\
\hline $\mathrm{G}$ & 0 & 1 & 4 & 2 & 0 & 0 & 0 & 0 & 7 & 2 & 0 & 0 & 0 & 16 \\
\hline $\mathrm{H}$ & 7 & 0 & 5 & 0 & 0 & 0 & 4 & 1 & 0 & 0 & 0 & 0 & 0 & 17 \\
\hline I & 0 & 1 & 1 & 0 & 6 & 0 & 0 & 0 & 3 & 0 & 9 & 0 & 0 & 20 \\
\hline $\mathrm{J}$ & 0 & 5 & 0 & 9 & 0 & 0 & 6 & 0 & 0 & 4 & 0 & 0 & 7 & 31 \\
\hline $\mathrm{K}$ & 3 & 0 & 8 & 0 & 0 & 6 & 0 & 0 & 2 & 0 & 0 & 3 & 0 & 22 \\
\hline $\mathrm{L}$ & 0 & 0 & 4 & 0 & 3 & 0 & 0 & 0 & 6 & 0 & 8 & 0 & 2 & 23 \\
\hline M & 5 & 0 & 0 & 0 & 1 & 4 & 0 & 0 & 7 & 2 & 0 & 0 & 3 & 22 \\
\hline $\mathrm{N}$ & 0 & 6 & 1 & 0 & 0 & 5 & 0 & 3 & 8 & 0 & 0 & 0 & 0 & 23 \\
\hline $\mathrm{O}$ & 7 & 0 & 0 & 5 & 1 & 2 & 0 & 0 & 6 & 0 & 0 & 8 & 0 & 29 \\
\hline$P$ & 0 & 5 & 0 & 3 & 0 & 1 & 0 & 9 & 0 & 0 & 2 & 0 & 0 & 20 \\
\hline Q & 10 & 0 & 0 & 0 & 0 & 0 & 3 & 5 & 1 & 0 & 0 & 0 & 1 & 20 \\
\hline $\mathrm{R}$ & 0 & 0 & 3 & 0 & 8 & 2 & 0 & 0 & 0 & 0 & 0 & 7 & 5 & 25 \\
\hline$S$ & 0 & 7 & 0 & 0 & 8 & 0 & 0 & 0 & 5 & 0 & 1 & 3 & 0 & 24 \\
\hline $\mathrm{T}$ & 1 & 0 & 0 & 5 & 0 & 2 & 0 & 8 & 0 & 4 & 0 & 0 & 3 & 23 \\
\hline $\mathrm{U}$ & 1 & 0 & 0 & 9 & 0 & 0 & 3 & 0 & 0 & 4 & 0 & 0 & 0 & 17 \\
\hline Total & 48 & 33 & 44 & 38 & 38 & 31 & 29 & 40 & 57 & 25 & 28 & 28 & 29 & 468 \\
\hline *Mean/ unit area & 2 & 2 & 2 & 2 & 2 & 1 & 1 & 2 & 3 & 1 & 1 & 1 & 1 & - \\
\hline
\end{tabular}

* Mean is rounded off to the nearest integer 


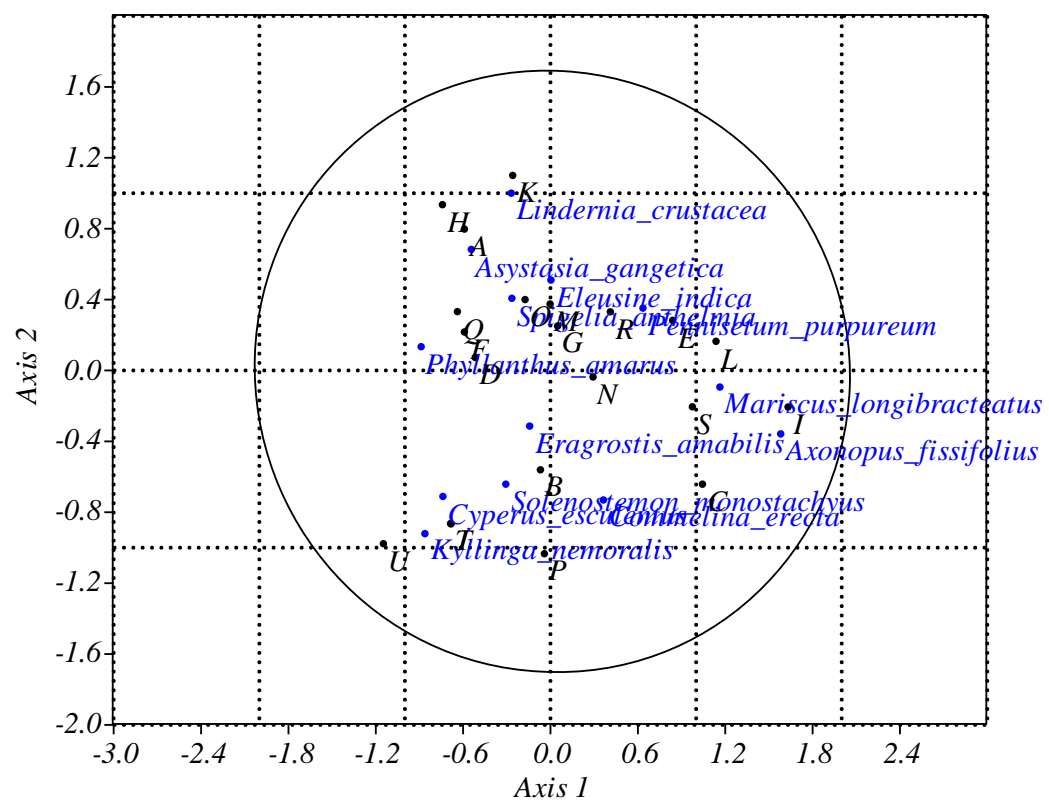

(A)

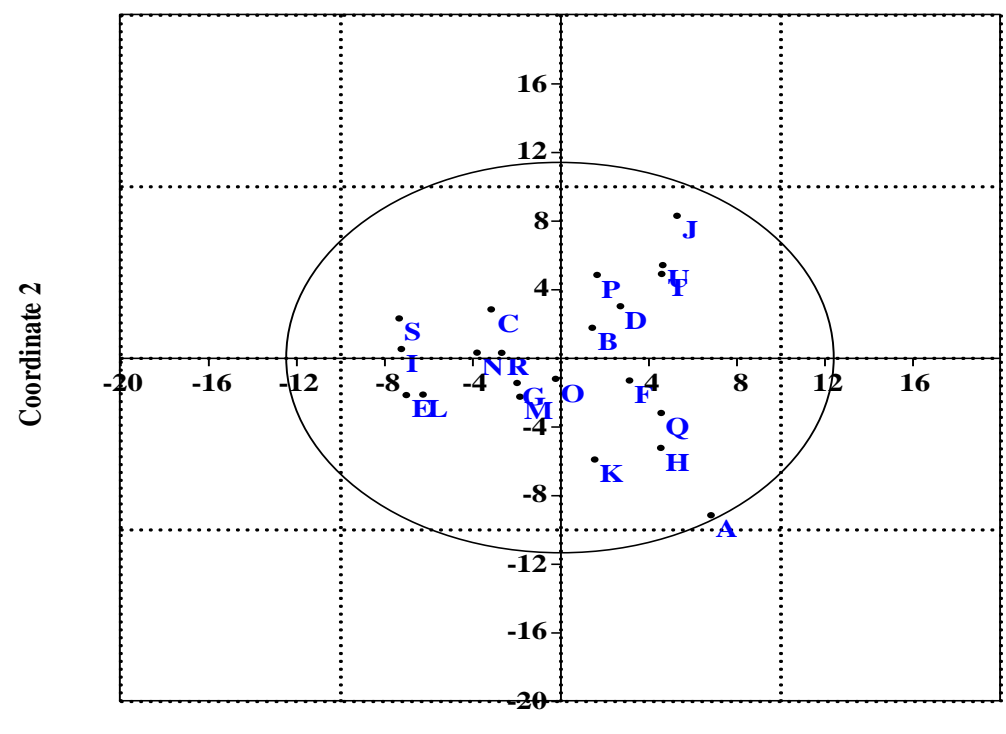

(B)

Coordinate 1

Figure 2: Correspondence biplot (A) and Principal coordinates establishing relationship (B) among sampling locations and associated weed species 
Table 4: Diversity indices of weed species associated with test plant collected from various sampling locations

\begin{tabular}{|c|c|c|c|c|c|c|c|c|c|c|c|c|c|}
\hline & 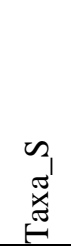 & 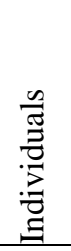 & 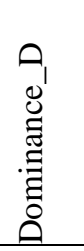 & 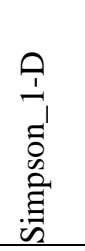 & 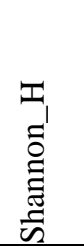 & 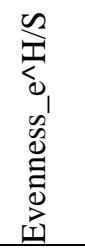 & 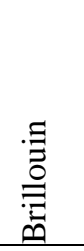 & 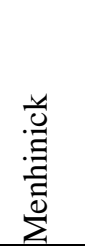 & 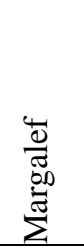 & 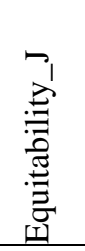 & 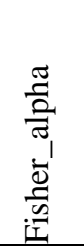 & 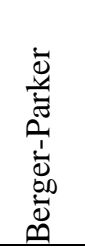 & $\begin{array}{l}\vec{j} \\
\dot{d} \\
\tilde{U}\end{array}$ \\
\hline $\bar{A}$ & 6 & 31 & 0.26 & 0.74 & 1.51 & 0.75 & 1.29 & 1.08 & 1.46 & 0.84 & 2.22 & 0.39 & 7.00 \\
\hline B & 6 & 22 & 0.21 & 0.79 & 1.67 & 0.88 & 1.36 & 1.28 & 1.62 & 0.93 & 2.72 & 0.32 & 6.00 \\
\hline $\mathrm{C}$ & 5 & 17 & 0.22 & 0.78 & 1.56 & 0.96 & 1.25 & 1.21 & 1.41 & 0.97 & 2.39 & 0.29 & 5.00 \\
\hline D & 6 & 25 & 0.21 & 0.79 & 1.65 & 0.86 & 1.37 & 1.20 & 1.55 & 0.92 & 2.50 & 0.28 & 6.00 \\
\hline $\mathrm{E}$ & 6 & 21 & 0.33 & 0.67 & 1.39 & 0.67 & 1.11 & 1.31 & 1.64 & 0.78 & 2.81 & 0.52 & 6.33 \\
\hline F & 5 & 20 & 0.23 & 0.78 & 1.54 & 0.94 & 1.27 & 1.12 & 1.34 & 0.96 & 2.14 & 0.30 & 5.00 \\
\hline $\mathrm{G}$ & 5 & 16 & 0.29 & 0.71 & 1.40 & 0.81 & 1.10 & 1.25 & 1.44 & 0.87 & 2.50 & 0.44 & 5.00 \\
\hline $\mathrm{H}$ & 4 & 17 & 0.31 & 0.69 & 1.23 & 0.86 & 1.00 & 0.97 & 1.06 & 0.89 & 1.65 & 0.41 & 4.00 \\
\hline I & 5 & 20 & 0.32 & 0.68 & 1.31 & 0.74 & 1.06 & 1.12 & 1.34 & 0.81 & 2.14 & 0.45 & 6.00 \\
\hline $\mathrm{J}$ & 5 & 31 & 0.22 & 0.78 & 1.57 & 0.96 & 1.36 & 0.90 & 1.17 & 0.98 & 1.69 & 0.29 & 5.00 \\
\hline $\mathrm{K}$ & 5 & 22 & 0.25 & 0.75 & 1.48 & 0.88 & 1.23 & 1.07 & 1.29 & 0.92 & 2.02 & 0.36 & 5.00 \\
\hline $\mathrm{L}$ & 5 & 23 & 0.24 & 0.76 & 1.50 & 0.90 & 1.25 & 1.04 & 1.28 & 0.93 & 1.97 & 0.35 & 5.00 \\
\hline $\mathrm{M}$ & 6 & 22 & 0.21 & 0.79 & 1.64 & 0.86 & 1.34 & 1.28 & 1.62 & 0.92 & 2.72 & 0.32 & 6.00 \\
\hline $\mathrm{N}$ & 5 & $23 \mathrm{~s}$ & 0.26 & 0.74 & 1.45 & 0.85 & 1.21 & 1.04 & 1.28 & 0.90 & 1.97 & 0.35 & 5.00 \\
\hline $\mathrm{O}$ & 6 & 29 & 0.21 & 0.79 & 1.63 & 0.85 & 1.38 & 1.11 & 1.49 & 0.91 & 2.30 & 0.28 & 6.00 \\
\hline $\mathrm{P}$ & 5 & 20 & 0.30 & 0.70 & 1.37 & 0.79 & 1.11 & 1.12 & 1.34 & 0.85 & 2.14 & 0.45 & 5.00 \\
\hline Q & 5 & 20 & 0.34 & 0.66 & 1.28 & 0.72 & 1.03 & 1.12 & 1.34 & 0.79 & 2.14 & 0.50 & 6.00 \\
\hline $\mathrm{R}$ & 5 & 25 & 0.24 & 0.76 & 1.50 & 0.90 & 1.26 & 1.00 & 1.24 & 0.93 & 1.88 & 0.32 & 5.00 \\
\hline$S$ & 5 & 24 & 0.26 & 0.74 & 1.45 & 0.85 & 1.21 & 1.02 & 1.26 & 0.90 & 1.92 & 0.33 & 5.00 \\
\hline $\mathrm{T}$ & 6 & 23 & 0.23 & 0.78 & 1.62 & 0.84 & 1.33 & 1.25 & 1.60 & 0.90 & 2.64 & 0.35 & 6.00 \\
\hline $\mathrm{U}$ & 4 & 17 & 0.37 & 0.63 & 1.15 & 0.79 & 0.93 & 0.97 & 1.06 & 0.83 & 1.65 & 0.53 & 4.00 \\
\hline
\end{tabular}

Key: A is the control location, Capitol. B is Uniben Hall 1 hostel.C is Ine filling station. D is Evidence church. E is Egor local government secretariat. $F$ is Mela motels. $G$ is Ediaken. $H$ is Edokpolor grammar school. I is new convenant gospel church. J is cemetery. $\mathrm{K}$ is Oando filling station. L is Ikpobabridge, Akpakpava. $M$ is Avbiama. $N$ is Oregbeni. O is Ramat park. $P$ is bye-pass. $Q$ is Pipeline road. $R$ is Iguomoroad. $S$ is Rehoboths food affair. $T$ is May-Ewere and Co. gas station. U is Bonedo petroleum Nigeria limited 
The genetic diversity of the test plant from different locations was assessed using RAPD marker. Genomic DNA was extracted from the test plants collected from 21 locations. The gel showed smeared DNA due to the weight of the DNA molecule extracted. Extract from location $\mathrm{P}$ appeared to be very faint while sample $\mathrm{Q}$ had the most intense smeared band (Figure 3). RAPD analysis was done using primer OPA 04 at an optimized annealing temperature. There were polymorphic bands in test samples I, J and K. The polymorphic pattern varied in sample J. Banding pattern of $\mathrm{K}$ was different, having a fragment of about $600 \mathrm{bp}$ absent in J. Another band of about $250 \mathrm{bp}$ was unique to sample $\mathrm{J}$ (Figure 4). Test samples from locations $\mathrm{Q}$ and $\mathrm{R}$ had monomorphic bands of 400bp which was not unique to $\mathrm{Q}$ and $\mathrm{R}$ but absent in $\mathrm{P}$ (Figure 5). The most diverse test samples were from location I, K, L, M and O having the highest polymorphism. There was no amplification in samples A, B, C, D, E, F, G, H, S, T and U. Primer OPA 03 was also used in another RAPD polymerase chain reaction at an optimized annealing temperature. There were monomorphic bands in test samples $\mathrm{J}$ and $\mathrm{P}$. The band size was about 400bp.

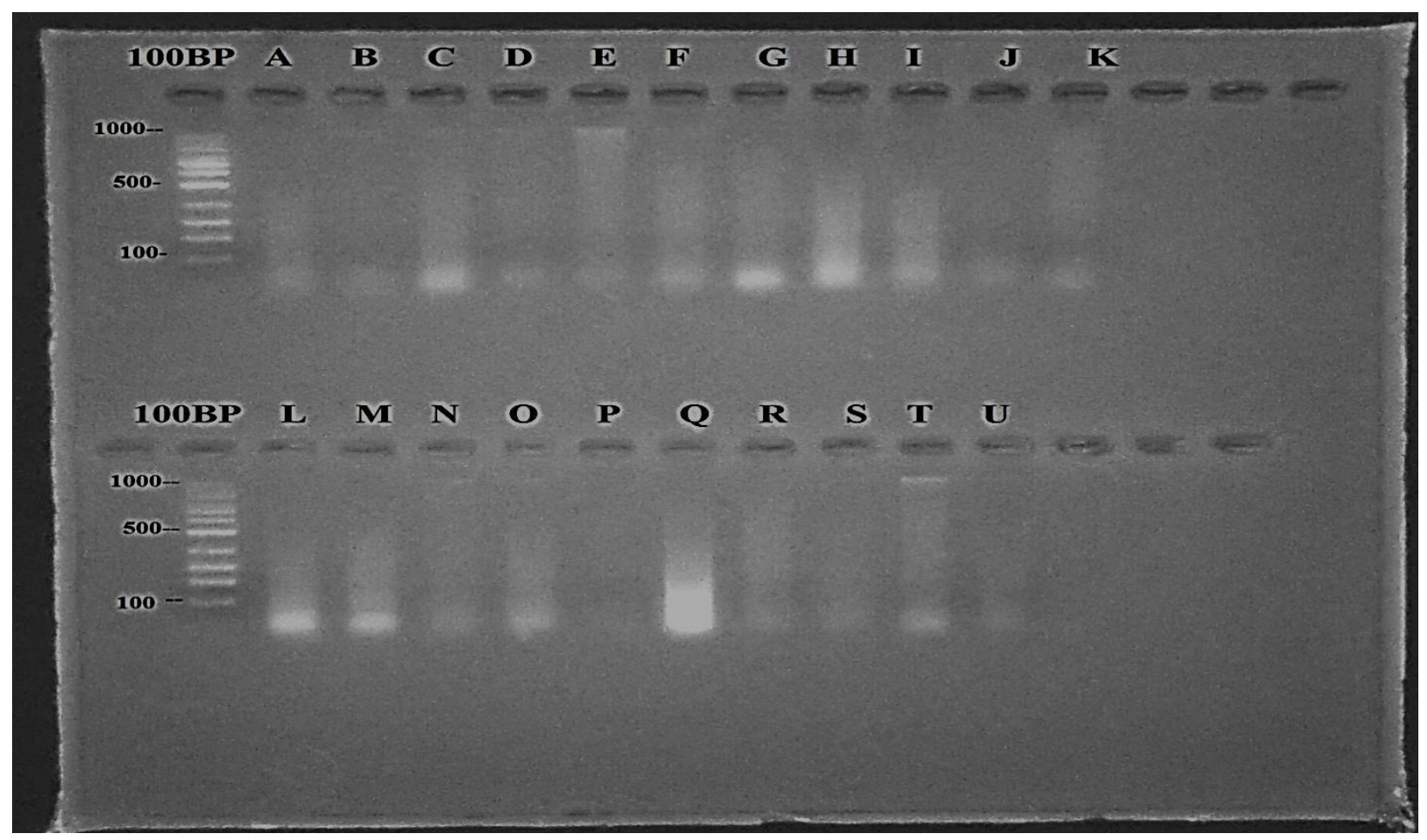

Figure 3: Gel photograph of genomic DNA extracted from test plant from 21 locations (A - U) 


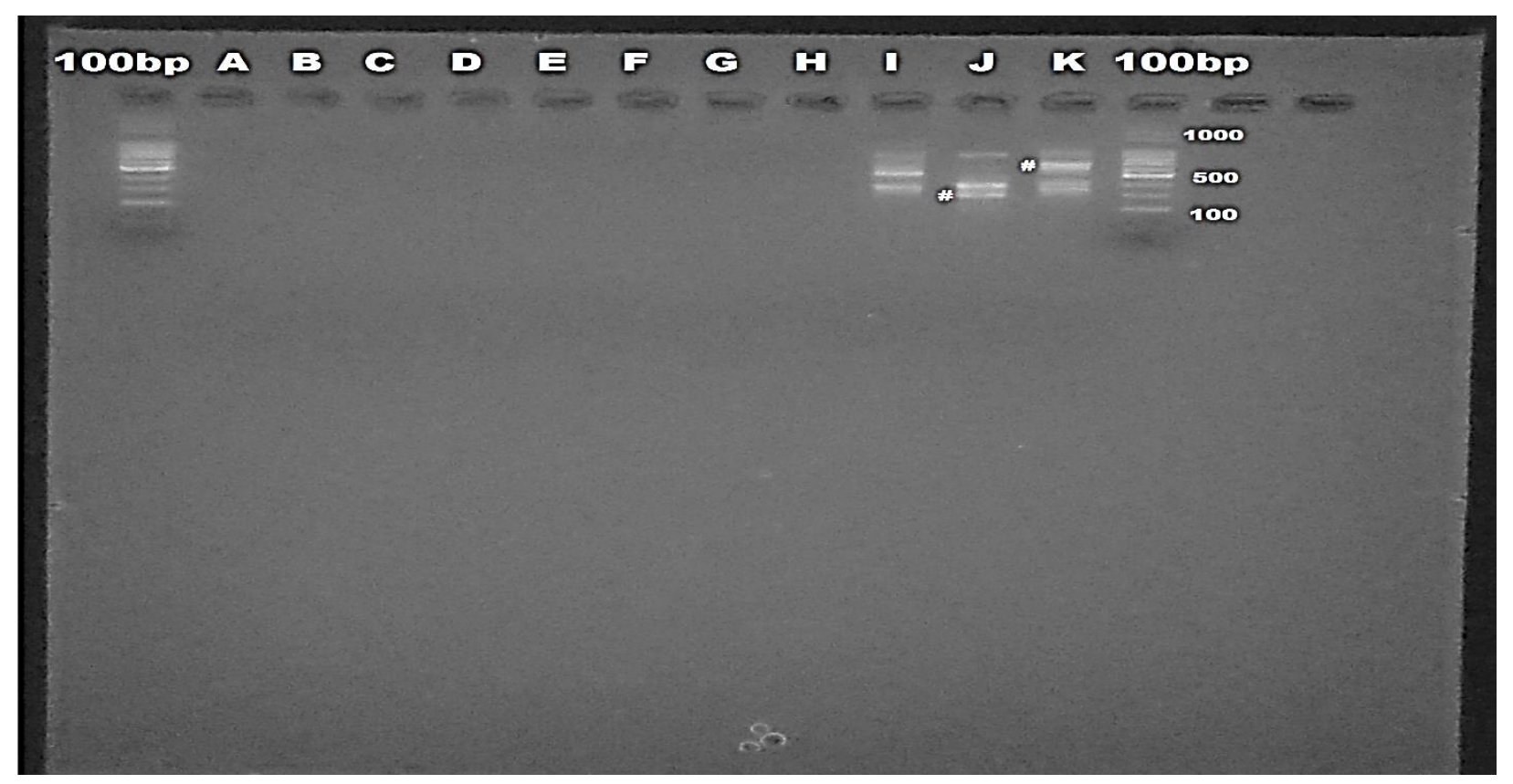

Figure 4: Gel photograph of RAPD analysis using primer OPA 04 and template from the test plant from 11 locations (A- k)

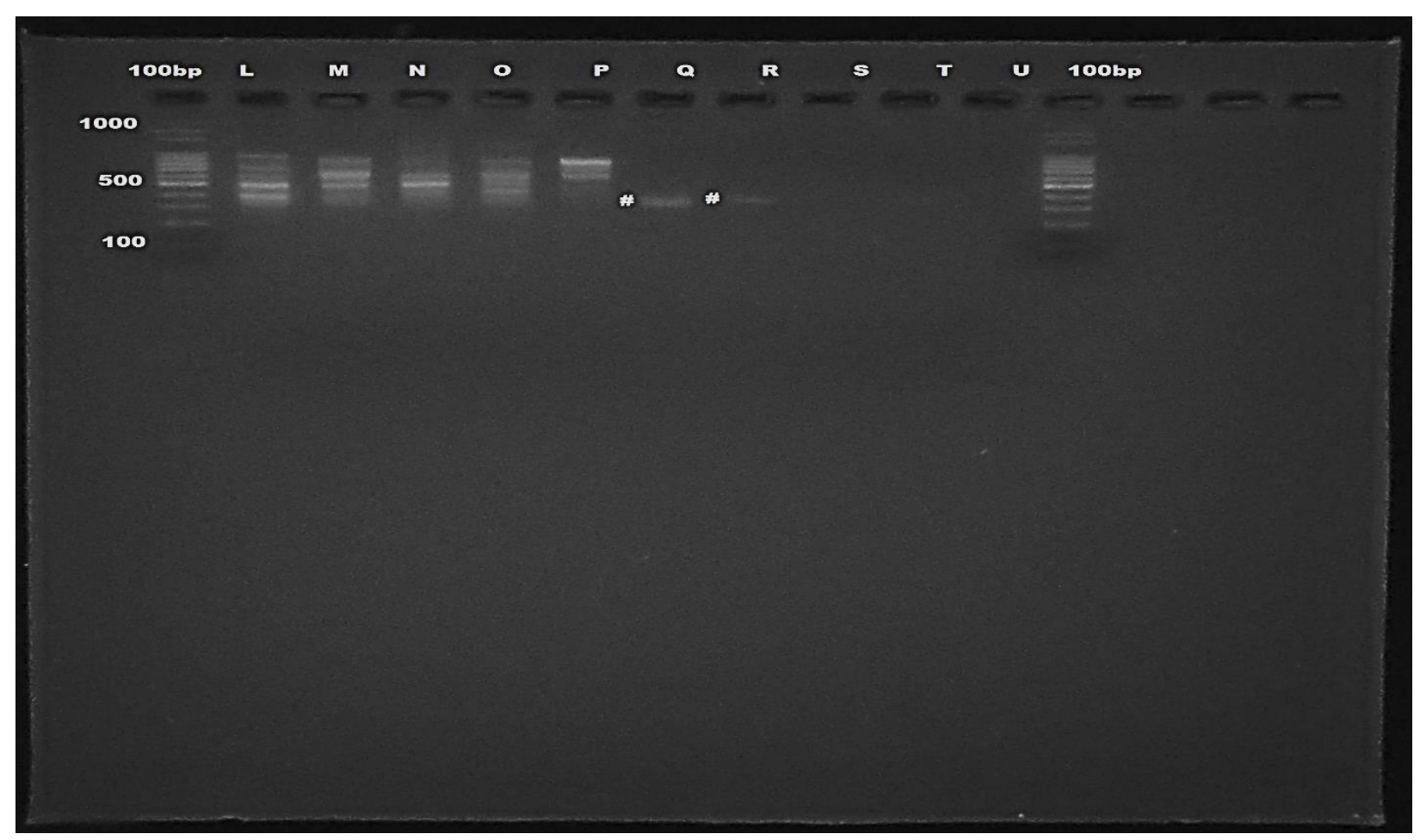

Figure 5: Gel photograph of RAPD analysis using primer OPA 04 and template from the test plant from 10 locations (L- U) 


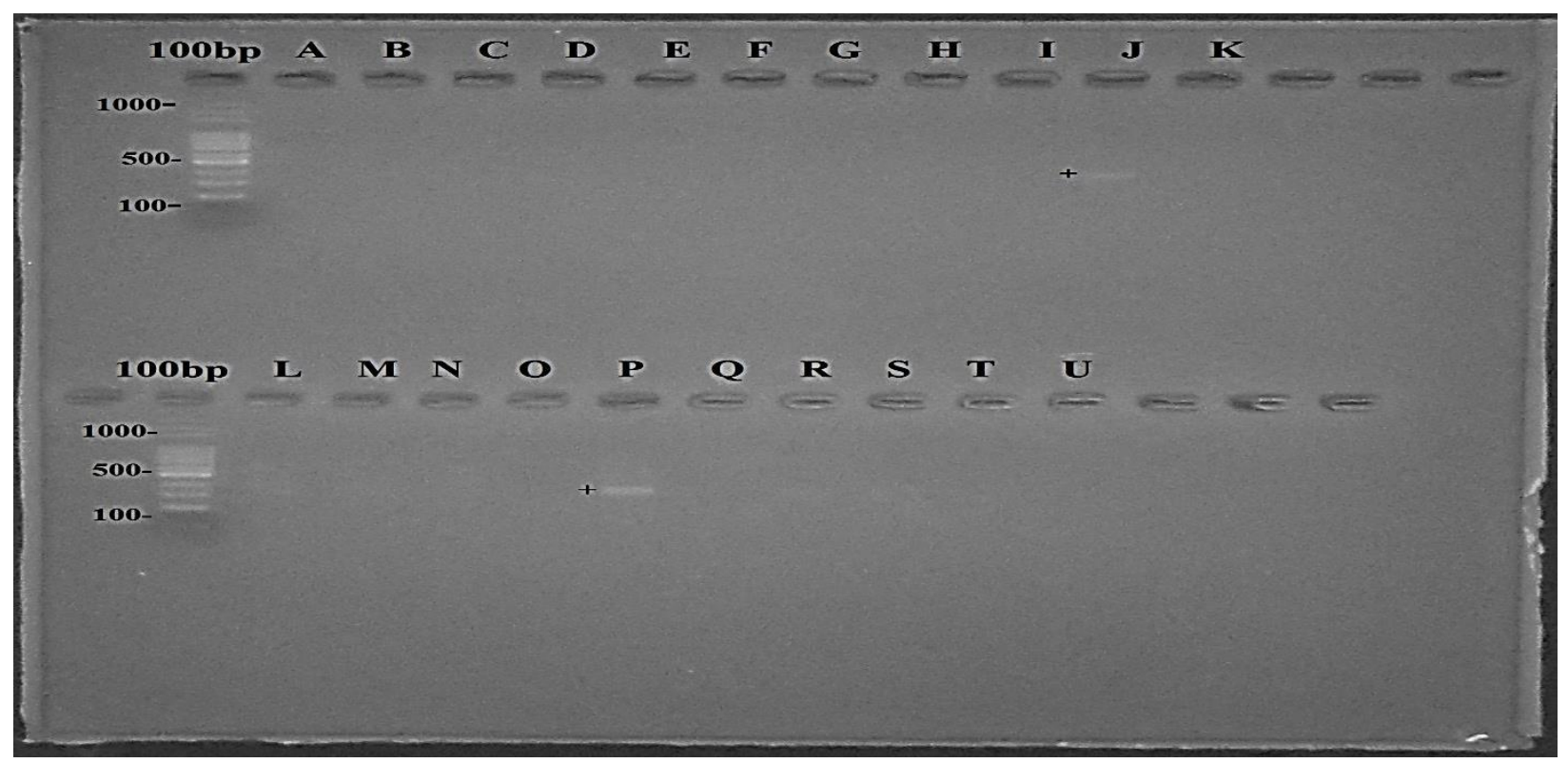

Figure 6: Gel photograph of RAPD analysis using primer OPA 03 and template from the test plant from 10 locations (A- U)

\section{DISCUSSION}

The genetic variation of an entire species is often called genetic diversity. Plant immediate environment play an important role in the growth and development of the plant (Upadhyaya et al., 2013). Height of a plant is essential in determining the plants life span and time to maturity. It is a major determinant of a species' ability to compete for light (Moles et al., 2009). The height parameter is an essential trait in plant breeding and cultivar development. In this study, significant variation was observed in the height of test plants collected from various locations. Though, the internode and length of inflorescence across location did not vary significantly (Table 1). The differences in plant height may be attributed to the effect of alterations in various environments or locations examined. A similar observation was reported in the height of maize plants (Sabiel et al., 2014).

Understanding the genetic diversity of the test plant (crab grass) in relation to the various environments studied usually includes its association with other plants or organisms. This study identified weeds associated with the test plant from the sampled locations and the weed abundance. This was to further determine the level of variation of the plants between locations (Musa and Ikhajiagbe, 2020). Pennisetum purpureum was the most abundant weed across the built-up locations. Some locations with less human activity and more activity recorded none or minimal emergence of $P$. purpureumin pots planted out with test plants. This observation may be due to the absence or reduced presence of elephant grass seeds in the rhizophere of the test plants from the locations. It is however evident that the variation in the locations examined did not correlate with the type and abundance of weed observed.

RAPD markers were assessed in the test plants to reveal possible genetic diversity across locations. It was observed that primer OPA 04 revealed a locus (about 600bp) that was absent in location J with minimum disturbance. Location $\mathrm{J}$ is a cemetery and it is not regularly trampled. This $600 \mathrm{pb}$ fragment was however observed in most samples from highly built up and trampled environment e.g locations I and K (See figure 4). It may be inferred that the man- 
made activities in these locations examined was responsible for the presence of the 600bp band in the test plants from those locations. This marker indicates variability in the genome of the test plants across the locations investigated. The samples with the highest polymorphism were from locations characterized by commercial activities and it may be deduced that the test genotypes obtained from these locations had denser genetic base when compared with plants from the control location, cemetery and probably those samples without amplification during PCR with OPA04. Further genetic studies in the test plants will definitely unravel more information on possible mutation in the plants examined.

\section{CONCLUSION}

The result obtained from this study indicated that there was genetic diversity among Digitaria horizontalis that were obtained from the different built areas investigated in Benin City. It simply means that human activities affect the genetic diversity of this plant.

\section{ACKNOWLEDGEMENTS}

This research received no specific grant from any funding agency in the public, commercial, or not-for-profit sectors. However, the authors appreciate the technical support of African Bioscience Laboratory, Ibadan, Nigeria with RAPDPCR.

\section{CONTRIBUTIONS OF THE AUTHORS}

The study was conceived by IB and AGO. Field and laboratory work was done by IB, OVD, UEO, AES, AO, and LPJ. Guide on genetic analyses was provided by OVD and OID. Statistical analyses of study were done by IB. First draft of manuscript was written by AES, AO, UEO, and LP-J under supervision of AGO and BI. All authors read an approved of the final manuscript.

\section{CONFLICTS OF INTEREST}

The authors declare no conflicts of interest. 


\section{REFERENCES}

Anonymous (n.d.). Digitaria horizontalis Willd. [online] WIKTROP Portal v2.0, Species Page: Digitaria horizontalis Willd. Available at: https://portal.wiktrop.org/biodiv/species/show/110 [Accessed date Mar 1, 2021].

Augusto, L., Ranger, J, Binkley, D., \& Rothe A. (2002). Impact of several common tree species of European temperate forests on soil fertility. Annals of Forest Science, 59: 233-253.

Barakat, M. N., Abdel Fattah, R. S., Badr, M., El-Turky, M. G. (2010). In vitro mutagenesis and identification of new variants via RAPD markers for improving chrysanthemum morifolium. African Journal of Agricultural Research, 5: 748 - 757.

Bell, F., Lamb, E., Sharma, M., Hunt, S., Madhur, A., \& Dacosta, J. (2016). Relative influence of climate, soils, and disturbance on plant species richness in northern temperate and boreal forests. Forest Ecology and Management, 381: 93-105.

Bhuyan, P., Khan, M. L, \& Tripathi, R. S. (2003). Tree diversity and population structure in undisturbed and humanimpacted stands of tropical wet evergreen forest in Arunachal Pradesh, Eastern Himalayas, India. Biodiversity and Conservation, 12: 1753-1773.

Bickham, K K. (2013). Long-term Effects of Multiple Disturbances on Soil Properties and Regeneration in a Colorado Subalpine Forest. Boulder, University of Colorado at Boulder: 35p.

Blanco, L. \& Pereira, V. (2015). Anthropogenic disturbances and the natural vegetation regeneration: A case study of forest fragment located in a Cuesta relief area Sao Paulo, Brazil. Open Journal of forestry, 3: 15-22.

Borrelli, P., Panagos, P., Märker, M., \& Schütt B. (2017). Assessment of the impacts of clear-cutting on soil loss by watererosion in Italian forests: First comprehensive monitoring and modelling approach. Catena, 149: 770781.

Hammer, O., Harper, D. A. T., \& Ryan, P. D. (2001). PAST: Paleontological statistical software package for education and data analysis. Palentologicia Electronica, 4(1): 9 - 15.

Harun, N., Chaudhry, A. S., Shaheen, S., Ullah, K., \& Khan F. (2017). Ethnobotanical studies of fodder grass resources for ruminant animals, based on the traditional knowledge of indigenous communities in Central Punjab Pakistan. Journal of Ethnobiology and Ethnomedicine 13: 56.

Johnson, D. E., \& Kent, R. J. (2002). The impact of cropping on weed species composition in rice after fallow across a hydrological gradient in west Africa. Weed Research. 42: 89-99

Latty, E. F., Canham, C. D., \& Marks, P. L. (2004). The effects of land-use history on soil properties and nutrient dynamics in northern hardwood forests of the Adirondack Mountains. Ecosystems, 7: 193 - 207.

Linares, J. C., Carreira, J. A., \& Ochoa, V. (2011). Human impacts drive forest structure and diversity. Insights from Mediterranean mountain forest dominated by Abiespinsapo (Boiss). European Journal of Forest Research, 130: $533-542$. 
Maynard, D. G., Paré, D., Thiffault, E., Lafleur, B., Hogg, K. E., \& Kishchuk, B. (2013). How do natural disturbance and human activities affect soils and tree nutrition and growth in the Canadian boreal forest? Environmental Reviews, 22: $161-178$.

Mishra, B. P., Tripathi, O. P., Tripathi, R. S., \& Pandey, H. N. (2004). Effects of anthropogenic disturbance on plant diversity and community structure of a sacred grove in Meghalaya, northeast India. Biodiversity and Conservation, 13: $421-436$.

Mligo, C. (2011). Antropogenic disturbance on the vegetation in Makurnge woodland, Bagamoyo District, Tanzania. Tanzania Journal of Science, 37: 94 - 108.

Moles, A. T., Warton, D. I., Warman, L., Swenson, N. G., Laffan, S. W., Zanne, A. E., Pitman, A., Hemmings, F. A. and Leishman, M. R. (2009). Global patterns in plant height. Journal of Ecology, 97: 923-932.

Musa, S. I., Ikhajiagbe, B. (2020). Assessment of physico-chemical properties of ferruginous ultisol in Benin city, Edo State - possible impact on plant distribution. Studia Universitatis "Vasile Goldiş", Seria Ştiinţele Vieţii, $30: 2,88-95$

Pare, D., Hilou, A., Ouedraogo, N., \& Guenne, S. (2016). Ethnobotanical Study of Medicinal Plants Used as AntiObesity Remedies in the Nomad and Hunter Communities of Burkina Faso. Medicines, 3(2): 9.

Pariente, S. (2002). Spatial patterns of soil moisture as affected by shrubs, in different climatic conditions. Environmental Monitoring and Assessment, 73: 237 - 251.

Ruprecht, E., Szabó, A., Enyedi, M. Z., \& Dengler, J. (2009). Stepplike grasslands in Transylvania (Romania): Characterisation and influence of management on species diversity and composition. Tuexenia, 29: $353-$ 368.

Sabiel, S. I. A., Abdelmula, A. A., Bashir, E. M. A., Khan, S., Yingying, S., Yang, Y., Baloch, S. U. \& Bashir, W. (2014). Genetic variation of plant height and stem diameter traits in maize (Zea mays L.) under drought stress at different growth stages. Journal of natural sciences research, 4(23): 116-122.

Shrestha, K., Maren, E., Arneberg, E., Sah, P., \& Vetaas R. (2012). Effect of anthropogenic disturbance on plant species diversity in oak forests in Nepal, Central Himalaya. International Journal of Biodiversity Science, Ecosystem Services \& Management, 9: $21-29$.

Upadhyaya, H. D., Wang, Y. H., Gowda, C. L. L., \& Sharma, S. (2013). Association mapping of maturity and plant height using SNP markers with the sorghum mini core collection. Theoretical Applied Genetics, 126:20032015.

Wilde, J., Waugh, R., \& Powell, W. (1992) Genetic fingerprinting of Theobroma clones using randomly amplified polymorphic DNA markers. Theoretical and Applied Genetics, 83: 871 - 877.

Williams, J. G. K., Kulelik, A. R., Livak, K. J., Rafalski, F. A., \& Tingey, S. V. (1990). DNA polymorphisms amplified by arbitrary primers are useful as genetic markers. Nucleic Acids Research, 18: 6531-6535.

Yaycili, O., \& Alikamanoğlu, S. (2012). Induction of salt-tolerant potato (Solanum tuberosum L.) mutants with gamma irradiation and characterization ofgenetic variations via RAPD-PCR analysis. Turkish Journal of Biology, 36: 405 - 412 